\title{
Effect of pregnancy on intake, digestibility and digesta kinetics in heifers fed urea treated rice straws*
}

\author{
E.K. Masha ${ }^{1}$, A.E. Kimambo ${ }^{1,4}$, N. Kanuya ${ }^{2}$, D.M. Mgheni ${ }^{1}$, \\ L.A. Mtenga ${ }^{1}$, M.R. Weisbjerg ${ }^{3}$, G.H. Laswai ${ }^{1}$, and T. Hvelplund ${ }^{3}$ \\ ${ }^{1}$ Sokoine University of Agriculture, Department of Animal Science and Production \\ P.O. Box 3004, Morogoro, Tanzania \\ ${ }^{2}$ Sokoine University of Agriculture, Department of Veterinary Surgery and Therionology \\ P.O. Box 3020, Morogoro, Tanzania \\ ${ }^{3}$ Danish Institute of Agricultural Sciences, Department of Animal Nutrition and Physiology \\ Foulum, P.O. Box 50, DK-8830 Tjele, Denmark
}

\begin{abstract}
Five rumen fistulated heifers weighing $298 \pm 4 \mathrm{~kg}$, fed ad libitum urea treated rice straw were used during trimesters 1,2 , and 3 of pregnancy. Voluntary dry matter intake (VDMI), dry matter (DM) and neutral detergent fibre (NDF) digestibility, rumen pool sizes and passage rates were measured. Indigestible NDF was measured by long incubation in situ and used to derive digesta kinetics. The VDMI, digestion and passage rates for DM and NDF fractions, increased $(\mathrm{P}<0.05)$ between the $1^{\text {st }}$ and $3^{\text {rd }}$ trimester. In conclusion, pregnant heifers fed high NDF based diets, maintains high forage intake by increasing digestion and passage rates.
\end{abstract}

KEY WORDS: heifers, pregnancy, intake, rumen pools, digesta kinetics

\section{INTRODUCTION}

Forages fed ad libitum in ruminants appear to be constrained by physical fill in the rumen, particularly during pregnancy, causing reduction in feed intake (Forbes, 1970). In addition, pregnancy increase total nutrients requirements. Hence, it is most likely that pregnant cows in the tropics, where poor quality roughage forms the basal diet, have a mechanism of coping with the physical limitation to intake during pregnancy. This study was carried out to measure the effects of different stages of pregnancy on the rumen pool sizes and digestion kinetics and their subsequent effects on intake by heifers fed ad libitum on high fibrous diets.

\footnotetext{
* Supported by DANIDA under ENRECA Project

${ }^{4}$ Corresponding author: e-mail: kimambo@suanet.ac.tz; kimambo@hotmail.com
} 


\section{MATERIAL AND METHODS}

Five rumen fistulated (Boran $\times$ Friesian) heifers with mean body weight of $298 \pm 4 \mathrm{~kg}$ were synchronised for oestrus and bred using artificial insemination. Three experimental periods, based on pregnancy trimesters were between $7^{\text {th }}$ and $11^{\text {th }}$ weeks of pregnancy (Trimester 1 ), $19^{\text {th }}$ to $23^{\text {rd }}$ weeks (Trimester 2 ) and $32^{\text {nd }}$ to $36^{\text {th }}$ weeks (Trimester 3 ). In each trimester, the experimental period lasted for 28 days.

Animals were housed in pens and fed individually. Experimental diet consisted of rice straws treated with $50 \mathrm{~g}$ urea/kg DM in $600 \mathrm{ml}$ of water per $\mathrm{kg} \mathrm{DM}$ straw, covered with polythene sheet and ensiled for 14 days. Animals were fed ad libitum twice a day at 9.00 and $15.00 \mathrm{~h}$ and each supplemented with fish meal $(200 \mathrm{~g})$, minerals $(100 \mathrm{~g})$ and urea $20 \mathrm{~g} / 100 \mathrm{~kg}$ body weight per day. Clean water was provided freely. Feed intake and in vivo digestibility were measured. Feeds were sampled at random. Rumen pool sizes of dry matter (DM) and neutral detergent fibre (NDF) were measured by rumen evacuation technique, whereas indigestible NDF (INDF) was determined by long incubation in situ, both as described by Mgheni et al. (2004). Rumen fractional rates of intake $\left(\mathrm{k}_{\mathrm{i}}\right)$, passage $\left(\mathrm{k}_{\mathrm{p}}\right)$ and digestion $\left(\mathrm{k}_{\mathrm{d}}\right)$ for DM, NDF and indigestible NDF were derived as described by Robinson et al. (1987). General Linear Model procedure of Statistical Analysis System (SAS) (1990) was used to analyse the data.

\section{RESULTS}

The mean values of voluntary dry matter intake (VDMI), rumen pool sizes, DM and NDF digestibility as influenced by stage of pregnancy are presented in Table 1.

Table 1. The effect of stage of pregnancy on feed DM and NDF intake $\left(\mathrm{kgd}^{-1}\right)$, digestibility (\%) and rumen pool sizes, $\mathrm{kg}$

\begin{tabular}{|c|c|c|c|c|c|c|}
\hline \multirow{2}{*}{ Item } & & \multicolumn{3}{|c|}{ Stage of pregnancy (trimester) ${ }^{1}$} & \multirow{2}{*}{ SEM } & \multirow{2}{*}{$\mathrm{P}$} \\
\hline & & 1 & 2 & 3 & & \\
\hline \multirow[t]{2}{*}{$\mathrm{DM}$} & Intake & $9.49^{\mathrm{c}}$ & $12.1^{\mathrm{b}}$ & $13.4^{\mathrm{a}}$ & 0.289 & 0.0001 \\
\hline & Digestibility & $63.2^{\mathrm{b}}$ & $69.8^{\mathrm{a}}$ & $66.9^{\mathrm{a}}$ & 1.070 & 0.0001 \\
\hline \multirow[t]{2}{*}{ NDF } & Intake & $7.17^{\mathrm{c}}$ & $8.45^{\mathrm{b}}$ & $9.43^{\mathrm{a}}$ & 0.143 & 0.0001 \\
\hline & Digestibility & 80.09 & 82.5 & 80.13 & 0.007 & 0.0672 \\
\hline \multicolumn{7}{|c|}{ Rumen pool sizes, $\mathrm{kg}$, of: } \\
\hline DM & & $9.21^{\mathrm{b}}$ & $12.4^{\mathrm{a}}$ & $8.93^{\mathrm{c}}$ & 0.28 & 0.001 \\
\hline $\mathrm{NDF}$ & & $5.58^{\mathrm{b}}$ & $7.63^{\mathrm{a}}$ & $5.41^{\mathrm{b}}$ & 0.179 & 0.001 \\
\hline INDF & & $1.89^{\mathrm{b}}$ & $2.26^{\mathrm{a}}$ & $2.51^{\mathrm{a}}$ & 0.085 & 0.009 \\
\hline
\end{tabular}

${ }^{1}$ in this and subsequent tables ${ }^{a, b, c}$ means within rows with different superscripts are different $(\mathrm{P}<0.05)$ 
There was an increase in DM and NDF intake between $1^{\text {st }}, 2^{\text {nd }}$ and $3^{\text {rd }}$ trimesters. Apparent digestibility coefficients increased between $1^{\text {st }}$ and $2^{\text {nd }}$ trimester and decreased slightly between $2^{\text {nd }}$ and $3^{\text {rd }}$ trimester for DM, with no difference for NDF (Table 1). The rumen pool sizes of DM and NDF increased from $1^{\text {st }}$ to $2^{\text {nd }}$ trimester followed by a decrease from $2^{\text {nd }}$ to $3^{\text {rd }}$ trimester. The pool size of indigestible NDF increased progressively between $1^{\text {st }}, 2^{\text {nd }}$ and $3^{\text {rd }}$ trimesters.

Derived rates of intake, digestion, passage and mean rumen retention time (MRRT) are presented in Table 2. Rate of intake for DM ( $\left.k_{i} D M\right), N D F\left(k_{i} N D F\right)$ and INDF $\left(\mathrm{k}_{\mathrm{i}} \mathrm{INDF}\right)$ increased as pregnancy progressed from $1^{\text {st }}$ to $3^{\text {rd }}$ trimester. Rate of digestion for DM $\left(\mathrm{k}_{\mathrm{d}} \mathrm{DM}\right)$, NDF $\left(\mathrm{k}_{\mathrm{d}} \mathrm{NDF}\right)$ and digestible NDF (DNDF), $\left(\mathrm{k}_{\mathrm{d}} \mathrm{DNDF}\right)$ increased during the same period. Passage rates of DM $\left(\mathrm{k}_{\mathrm{p}} \mathrm{DM}\right), \mathrm{NDF}$ $\left(\mathrm{k}_{\mathrm{p}} \mathrm{NDF}\right), \mathrm{k}_{\mathrm{d}} \mathrm{DNDF}$ and INDF ( $\mathrm{k}_{\mathrm{p}} \mathrm{INDF}$ ) response were also similar during the same period. The MRRT increased between $1^{\text {st }}$ and $2^{\text {nd }}$ trimester and decreased between $2^{\text {nd }}$ and $3^{\text {rd }}$ trimester for DM, NDF and INDF, whereas MRRT for DNDF decreased with advanced pregnancy.

Table 2. Digestion kinetics for DM and NDF fractions at different stages of pregnancy

\begin{tabular}{|c|c|c|c|c|c|c|}
\hline \multirow{2}{*}{\multicolumn{2}{|c|}{ Rates, $\% \mathrm{~h}^{-1}$}} & \multicolumn{3}{|c|}{ Stage of pregnancy (trimester) } & \multirow{2}{*}{ SEM } & \multirow{2}{*}{ P-value } \\
\hline & & 1 & 2 & 3 & & \\
\hline \multirow[t]{4}{*}{$\mathrm{DM}^{1}$} & $\mathrm{k}_{\mathrm{i}}$ & $4.3^{\mathrm{b}}$ & $4.14^{\mathrm{b}}$ & $6.36^{\mathrm{a}}$ & 0.030 & 0.001 \\
\hline & $\mathrm{k}_{\mathrm{d}}^{1}$ & $2.8^{\mathrm{b}}$ & $2.9^{\mathrm{b}}$ & $4.3^{\mathrm{a}}$ & 0.080 & 0.001 \\
\hline & $\mathrm{k}_{\mathrm{p}}$ & $1.6^{\mathrm{b}}$ & $1.24^{\mathrm{b}}$ & $2.1^{\mathrm{a}}$ & 0.001 & 0.001 \\
\hline & MRRT (h) & $64.26^{\mathrm{b}}$ & $81.42^{\mathrm{a}}$ & $48.03^{\mathrm{c}}$ & 3.740 & 0.050 \\
\hline \multirow[t]{4}{*}{$\mathrm{NDF}$} & $\mathrm{k}_{\mathrm{i}}$ & $5.45^{\mathrm{b}}$ & $4.71^{\mathrm{c}}$ & $7.37^{\mathrm{a}}$ & 0.001 & 0.001 \\
\hline & $\mathrm{k}_{\mathrm{p}}$ & $1.27^{\mathrm{b}}$ & $0.97^{\mathrm{c}}$ & $1.73^{\mathrm{a}}$ & 0.001 & 0.001 \\
\hline & $\mathrm{k}_{\mathrm{d}}^{\mathrm{p}}$ & $4.18^{\mathrm{b}}$ & $3.73^{\mathrm{c}}$ & $5.65^{\mathrm{a}}$ & 0.001 & 0.001 \\
\hline & MRRT (h) & $80.03^{\mathrm{b}}$ & $106.01^{\mathrm{a}}$ & $58.74^{\mathrm{c}}$ & 4.480 & 0.002 \\
\hline \multirow[t]{3}{*}{ INDF } & $\mathrm{k}_{\mathrm{i}}$ & $4.56^{\mathrm{b}}$ & $5.90^{\mathrm{a}}$ & $5.01^{\mathrm{b}}$ & 0.002 & 0.015 \\
\hline & $\mathrm{k}_{\mathrm{p}}$ & $2.23^{\mathrm{a}}$ & $1.90^{\mathrm{b}}$ & $2.01^{\mathrm{ab}}$ & 0.001 & 0.055 \\
\hline & MRRT (h) & $43.30^{\mathrm{b}}$ & $52.67^{\mathrm{a}}$ & $50.06^{\mathrm{ab}}$ & 1.730 & 0.014 \\
\hline \multirow[t]{4}{*}{ DNDF } & $\mathrm{k}_{\mathrm{i}}$ & $5.94^{\mathrm{b}}$ & $4.25^{\mathrm{c}}$ & $9.60^{\mathrm{a}}$ & 0.003 & 0.016 \\
\hline & $\mathrm{k}_{\mathrm{p}}^{1}$ & $0.77^{\mathrm{b}}$ & $0.58^{\mathrm{b}}$ & $1.52^{\mathrm{a}}$ & 0.007 & 0.020 \\
\hline & $\mathrm{k}_{\mathrm{d}}$ & $5.17^{\mathrm{b}}$ & $3.67^{\mathrm{c}}$ & $8.08^{\mathrm{a}}$ & 0.002 & 0.010 \\
\hline & MRRT (h) & $134.9^{\mathrm{b}}$ & $185.4^{\mathrm{a}}$ & $68.97^{\mathrm{c}}$ & 13.300 & 0.001 \\
\hline
\end{tabular}

${ }^{1} \mathrm{k}_{\mathrm{i}}=$ intake rate, $\mathrm{k}_{\mathrm{p}}=$ passage rate, $\mathrm{k}_{\mathrm{d}}=$ digestion rate, $\mathrm{MRRT}=$ mean rumen retention time

\section{DISCUSSION}

The observed progressive increase in intake and rumen pool sizes with more or less similar digestibility coefficients, as pregnancy advances is contrary to what was expected. This mechanism was possibly contributed to the increased passage and digestion rates with reduced MRRT during the last trimester. The 
current findings are in agreement with the work of Stanley et al. (1993) who reported increased VDMI and increased passage rate of $87 \%$ for indigestible acid detergent fibre (IADF) from 61 to 6 days before calving for Hereford $\times$ Angus cows consuming chopped lucerne hay. The results, however, are contrary to other findings of Journet and Remond (1976) that rumen contents and thus intake decreased proportionally with growth of foetus. The observed increase in rate of digestion of DM, NDF and DNDF between $1^{\text {st }}$ and $3^{\text {rd }}$ trimester can partly account for lack of well-known negative effects of increased passage rate on digestibility. In the present study, there is also a possibility of existence of rumen elasticity for fill that allowed space for increased intake.

\section{CONCLUSIONS}

It is concluded that pregnant animals fed high NDF based forages adapt to these diets and maintain high feed intake by increasing digestion and passage rates as pregnancy progresses. It is therefore recommended that pregnant animals should be fed readily digestible forages to enable them extract sufficient nutrients as pregnancy advances between $2^{\text {nd }}$ and $3^{\text {rd }}$ trimester.

\section{REFERENCES}

Forbes J.M., 1970. Voluntary food intake of pregnant ewes. J. Anim. Sci. 31, 1222-1227

Journet M., Remond B., 1976. Physiological factors affecting the voluntary intake of feed by cows. A review. Livest. Prod. Sci. 3, 129-146

Mgheni D.M., Weisbjerg M.R., Kimambo A.E., Hvelplund T., Madsen J., Mtenga L.A., 2004. Methods for determination of passage rates of fibre in tropical forages in mature non-pregnant dairy heifers. TAJAS 5, 11-20

Robinson P.H., Tamminga S., Van Vuuren A.M., 1987. Influence of declining level of feed intake and varying proportion of starch in the concentrate on rumen ingesta quantity, composition and kinetics of ingesta turnover in dairy cows. Livest. Prod. Sci. 17, 37-62

SAS, 1990. Statistical Analysis System. SAS Institute Inc. SAS/ STAT TM User's Guide, Release 6.03. Cary, NC

Stanley T.A., Cochran R.C., Vazant E.S., Harmon D.L., Conrad H.R., 1993. Periparturient changes in intake, ruminal capacity and digestive characteristics in beef cow consuming alfalfa hay. J. Anim. Sci. 71, 789-795 